\title{
PENGELOLAAN KELAS ONLINE MELALUI PENGGUNAAN GOOGLE CLASSROOM DAN VIDEO PEMBELAJARAN BAGI GURU-GURU SMA NEGERI 1 SIDIKALANG
}

\author{
Osco Parmonangan Sijabat ${ }^{*}$, Lisbet Novianti Sihombing², David Berthony \\ Manalu $^{3}$, Susy Alestriani Sibagariang ${ }^{4}$, Esti Marlina Sirait ${ }^{5}$, Novra Melisa \\ Hutabarat ${ }^{6}$, Nurliani Siregar ${ }^{7}$, Ronald Hasibuan ${ }^{8}$, Injen Pardamean Butar-Butar', \\ Herlina Hotmadinar Sianipar10, Bangun Munte ${ }^{11}$, Rianita Simamora ${ }^{12}$.
}

\author{
1,2,3,4,5,6 Universitas HKBP Nommensen Pematangsiantar \\ 7,8,9,10,11,12 Universitas HKBP Nommensen Medan \\ *Penulis Koresponsensi, email: oscosijabat@uhn.ac.id
}

\begin{abstract}
The online learning system (in the network) is a learning system without face to face directly between teachers and students but is carried out online using the internet network. Educators must ensure that teaching and learning activities continue to run according to the demands of the curriculum, even though students are at home. With a situation like this, teachers are required to make learning innovations related to the media that will be used to deliver online learning effectively. The diversity of teacher competency levels in carrying out online learning requires socialization activities for online classroom management in terms of using google classroom and making learning videos uploaded to youtube. Seeing these conditions, the service team from HKBP Nommensen University lecturers collaborated with school leaders at SMA Negeri 1 Sidikalang in terms of conducting socialization activities and online classroom management training through the learning media of google classroom and making learning videos uploaded on youtube. The results of the collaboration in the form of community service activities carried out can help teachers at SMA Negeri 1 Sidikalang as evidenced by the average teacher already having online classes and being able to manage online classes through Google Classroom and make good learning videos.
\end{abstract}

Keywords: Online class, Google classroom, Learning video.

\begin{abstract}
Abstrak. Sistem pembelajaran daring (dalam jaringan) merupakan sistem pembelajaran tanpa tatap muka secara langsung antara guru dan siswa tetapi dilakukan melalui online yang menggunakan jaringan internet. Para pendidik harus memastikan kegiatan belajar mengajar tetap berjalan sesuai dengan tuntutan kurikulum, meskipun siswa berada di rumah. Dengan situasi seperti ini para guru dituntut untuk melakukan inovasi pembelajaran terkait media yang akan digunakan untuk penyampaian pembelajaran daring tersebut secara efektif. Keragaman tingkat kompetensi guru dalam melaksanakan pembelajaran daring memerlukan adanya kegiatan sosialisasi pengelolaan kelas online dalam hal penggunaan google classroom dan pembuatan video pembelajaran yang diuploud ke youtobe. Melihat kondisi tersebut, para tim pengabdi dari dosen universitas HKBP Nommensen melakukan kerjasama dengan pimpinan sekolah di SMA Negeri 1 Sidikalang dalam hal melakukan kegiatan sosialisasi dan pelatihan pengelolaan kelas online melalui media pembelajaran google classroom dan pembuatan video pembelajaran yang di upload di youtube. Hasil kerjasama dalam bentuk kegiatan pengabdian masyarakat yang dilakukan dapat membantu para guru yang ada di SMA Negeri 1 Sidikalang yang dibuktikan dengan rata-rata para guru sudah mempunyai kelas online dan dapat melakukan pengelolaan kelas online melalui google classroom serta membuat video pembelajaran dengan baik.
\end{abstract}

Kata Kunci: Kelas online, Google classroom, Video pembelajaran.

How to Cite: Sijabat, O.P., Sihombing, L.N., Manalu, D.B., Sibagariang, S.A., Sirait, E.M., Hutabarat, N.M., Siregar, N., Hasibuan, N., Butar-Butar,I.P., Sianipar, H.H., Munte, B., \& Simamora, R.(2021). Pengelolaan Kelas Online melalui Penggunaan Google Classroom dan Video Pembelajaran bagi Guru-Guru Sma Negeri 1 Sidikalang. Mitra Mahajana: Jurnal Pengabdian Masyarakat, 2(3) 226-231. doi: https://doi.org/10.37478/mahajana.v2i3.1231

\section{PENDAHULUAN}

Wabah virus corona mempengaruhi berbagai aspek kehidupan, tak terkecuali pendidikan. Aktivitas pembelajaran semua jenjang pendidikan di Indonesia dilakukan dari rumah. Mempertimbangkan efektivitas, keamanan dan kenyamanan, metode pembelajaran online 
Osco Parmonangan Sijabat, Lisbet Novianti Sihombing, David Berthony Manalu, Susy Alestriani Sibagariang, Esti Marlina Sirait, Novra Melisa Hutabarat , Nurliani Siregar, Ronald Hasibuan, Injen Pardamean Butar-Butar, Herlina Hotmadinar Sianipar, Bangun Munte , Rianita Simamora

Mitra Mahajana: Jurnal Pengabdian Masyarakat 2(3), 2021, 226-231

secara penuh menjadi pilihan di tengah pandemi yang diharus pembatasan sosial. Kementerian Pendidikan dan Kebudayaan pun memperpanjang masa belajar dari rumahkarena situasi yang belum kondusif. Dengan mempertimbangkan efektivitas, keamanan, dan kenyamanan, pembelajaran melalui e-learning dipilih hampir di seluruh jenjang pendidikan di Indonesia. Elearning merupakan sebuah sistem maupun konsep pendidikan yang memanfaatkan teknologi informasi dalam proses belajar pembelajaran. (Hanum, 2013). Dosen dan guru dalam memanfaatkan teknologi informasi, harus kreatif. Materi pembelajaran diupayakan yang semua peserta didik dapat menerima dan juga tidak kesulitan dalam mengaksesnya. Sekolah dapat memilih Learning Management System ( LMS) yang sesuai dengan kondisi sekolah masingmasing dan guru yang berkomunikasi langsung dengan siswa dapat memilih konten dan media yang dapat menarik peserta didik sehingga proses pembelajaran dengan sistem e-learning bukan menjadikan beban bagi siswa tetapi merupakan pembekalan kemandirian siswa (Permata, 2020). Pada masa new normal ini semua sekolah menyiapkan pendidikan dengan sistem e- learning, demikian juga dengan SMA Negeri 1 Sidikalang yang sebagian besar para guru sudah mempersiapkan sekenario pembelajaran daring tersebut, tetapi mereka kesulitan dalam mengemas materi yang akan disajikan secara daring. Rata-rata para guru juga hanya menggunakan media sosial (Whatsapp) sebagai penyampaian materi pembelajaran dan belum memahami penggunaan media Learning Management System ( LMS) sesuai anjuran dari kementrian pendidikan dan kebudayaan tersebut (OP.Sijabat, 2021). Melihat kondisi tersebut, para tim pengabdi dari dosen Universitas HKBP Nommensen melakukan kerjasama dengan pimpinan sekolah di SMA Negeri 1 Sidikalang dalam hal melakukan pendampingan sosialisasi dan pelatihan pengelolaan kelas online dengan tujuan membantu para-guru-guru untuk dapat melakukan proses pembelajaran selama daring secara efektif dan efisien.

\section{METODE PELAKSANAAN}

Dalam teknis pelaksanaan program kegiatan pengabdian kepada masyarakat (PKM) ini, para tim dosen selaku pengabdi mendata kembali anggota kelompok yang akan mengikuti pembimbingan dan pendampingan pengelolaan kelas online. Adapun para tim dosen selaku pengabdi antara lain: 1). Osco Parmonangan Sijabat, S.Pd., M.Pd., 2). Lisbet Novianti Sihombing, S.Pd., M.Pd., 3). David Berthony Manalu, S.Pd., M.Pd., 4). Susy Alestriani Sibagariang, S.Pd., M.M., 5). Pdt. Esti Marlina Sirait, M.Th., 6). Novra Melisa Hutabarat, S.Pd., M.Hum., 7). Dr. Nurliani Siregar, M.Pd., 8). Drs. Ronald Hasibuan, M.Pd., 9). Injen Pardamean Butar-Butar, S.Pd., M.Si., 10). Dra. Herlina Hotmadinar Sianipar, M.Si., 11). Bangun Munte, S.Pd., M.M dan 12). Rianita Simamora, S.Pd., M.Pd. Kegiatan ini dilaksanakan selama 2 hari yaitu hari Jumat dan Sabtu tanggal 17-18 September 2021. Sedangkan peserta dari kegiatan ini meliputi tenaga kependidikan dan non kependidikan, staf dan pegawai administrasi disekolah tersebut sejumlah 42 orang. Secara garis besar kegiatan ini dilakukan dengan 3 tahap yaitu, tahap persiapan, tahap pelaksanaan, dan tahap pelaporan sekaligus evaluasi hasil pelaksanaan.

\section{A. Tahap PersiapanKegiatan}

Adapun kegiatan yang dilakukan dalam proses persiapan dapat diuraikan sebagai berikut:

1. Analisis Situasi Kebutuhan Masyarakat

Tahap ini dilakukan untuk menentukan kalayak sasaran dan bidang permasalahan yang akan diselesaikan. Pada tahap ini dilakukan survei ke SMA Negeri 1 Sidikalang. Disamping survey juga dilakukan wawancara kepada kepala sekolah, wakasek bidang kurikulum, dan para guru mengenai kebutuhan para guru di SMA Negeri 1 Sidikalang, khususnya yang berkaitan dengan kompetensi pembelajaran daring.

2. Indentifikasi masalah

Berdasarkan hasil analisis situasi dan kebutuhan dilakukan identifikasi dan perumusan masalah-masalah khusus yang dihadapi oleh kelompok sasaran. Dalamhal ini kelompok sasaran adalah guru-guru di SMA Negeri 1 Sidikalang.

3. Menentukan Tujuan Kerja

Pada tahap ini ditentukan kondisi baru yang akan dicapai/dihasilkan melalui kegiatan 
Osco Parmonangan Sijabat, Lisbet Novianti Sihombing, David Berthony Manalu, Susy Alestriani Sibagariang, Esti Marlina Sirait, Novra Melisa Hutabarat , Nurliani Siregar, Ronald Hasibuan, Injen Pardamean Butar-Butar, Herlina Hotmadinar Sianipar, Bangun Munte , Rianita Simamora

Mitra Mahajana: Jurnal Pengabdian Masyarakat 2(3), 2021, 226-231

pengabdian masyarakat ini. Kondisi baru adalah jawaban dari masalah yang telah dirumuskan.

4. Tehnik Pemecahan Masalah

Masalah yang sudah diidentifikasi perlu dipecahkan dan sekaligus mencapai tujuan (kondisi baru) yang telah ditetapkan. Pada tahap ini dilakukan dengan mencari alternative pemecahan masalah dan selanjutnya memilih alternatif terbaikyang dapat dilakukan dengan memperhatikan situasi dan kondisi kelompok sasaran dan pelaksana kegiatan. Alternatif yang dipilih adalah berdasarkan hasil pengolahan data sebelum pelatihan dilakukan pre-test dan setelah kegiatan pelatihan berlangsung dilakukan post-test. Dari hasil yang diperoleh nantinya dapat disimpulkan mana yang paling banyak memberikan keuntungan, paling sedikit memiliki kelemahan, dan paling sedikit memberikan kerugian, sehingga dapat dilakukan tindak lanjut dari proses kegiatan tersebut di hari yang akan datang.

\section{B. Tahap Pelaksanaan Kegiatan}

Pelaksanaan kegiatan ini dilakukan selama 2 hari dengan kegiatan sosialisasi dan workshop pembelajaran daring di hari pertama dengan 6 orang tim dosen yang bertugas menyampaikan materi, serta kegiatan pendampingan pengelolaan kelas online berupa google classsroom dan pembuatan youtube di hari kedua bersama 6 orang tim dosen lainnya. Secara detail kegiatan tersebut dapat diuraikan sebagai berikut:

1. Sosialisasi dan Workshop Pembelajaran Daring

Permasalahan bahwa banyak guru yang belum memiliki kemampuan yang cukup dalam memanfaatkan LMS sebagai media pembelajaran daring. Sosialisasi dan workshop dengan materi baku dan disesuaikan dengan kebutuhan praktis para guru. Pelatihan secara sinkron dilakukan di SMA Negeri 1 Sidikalang secara luring dan dilakukan secara daring sinkron menggunakan video tutorial yang dibuat oleh Dosen Universitas HKBP Nommensen Medan dan Pematangsiantar.

2. Pendampingan Pengelolaan Kelas Online dan Pembuatan Youtube Pembelajaran

Pendampingan dilakukan sebagai tindak lanjut pelatihan yang merupakan implementasi kemampuan mengelola kelas daring, yang terdiri dari: membuat kelas, mengelola materi pembelajaran, membuat quiz dan ujian online, melakukan pengasuhan aktifitas belajar (memeriksa hasil pekerjaan siswa serta memberikan umpan balik secara daring), dan pembuatan video pembelajaran.

\section{Tahap Pelaporan dan Evaluasi Hasil Kegiatan}

Pada setiap tahap dilakukan evaluasi sehingga timbul keyakianan bahwa segala sesuatu yang telah diputuskan adalah benar, dan dapat melangkah ke tahap berikutnya dengan aman. Apabila hasil evaluasi menunjukan kekurangan atau kelemahan maka dilakukan penyempurnaan atau penyesuaian. Pada akhir kegiatan dilakukan analisa terhadap ketercapaian tujuan dan dampak dari keseluruhan kegiatan pengabdian masyarakat terhadap khalayak sasaran. Evaluasi juga dilakukan terhadap seluruh pelaksanaan kegiatan. Selanjutnya dilakukan penyusunan laporan. Sebagai bentuk pertanggungjawaban pelaksanaan kegiatan pengabdian masyarakat yang telah dilakukan.

\section{HASIL DAN PEMBAHASAN}

Setelah dilakukan program kegiatan pengabdian ini dan dilakukan evaluasi terhadap proses dan hasil, maka diperoleh hasil sebagai berikut :

1. Pelatihan penggunaan media Learning Management System ( LMS) telah selesai dan lancar dilaksanakan dengan diikuti oleh 40 orang guru dan 2 orang tenaga kependidikan (staff administrasi kepegawaian). Materi pelatihan adalah Pengelolaan media Learning Management System ( LMS) Google Classroom yang terdiri dari: membuat kelas, mengelola materi pembelajaran, membuat quiz dan ujian online, melakukan pengasuhan aktifitas belajar (memeriksa hasil pekerjaan dan memberikan umpan balik), dan pembuatan video 
Osco Parmonangan Sijabat, Lisbet Novianti Sihombing, David Berthony Manalu, Susy Alestriani Sibagariang, Esti Marlina Sirait, Novra Melisa Hutabarat, Nurliani Siregar, Ronald Hasibuan, Injen Pardamean Butar-Butar, Herlina Hotmadinar Sianipar, Bangun Munte , Rianita Simamora

pembelajaran.

Mitra Mahajana: Jurnal Pengabdian Masyarakat 2(3), 2021, 226-231

2. Selanjutnya dilakukan pendampingan pelaksanaan pembelajaran daring yang didampingi dosen sebagai tim pengabdi.

3. Kegairahan guru dalam melakukan pengasuhan kelas dan pengasuhan aktifitas belajar sangat baik, ditunjukkan antusiasme para guru.

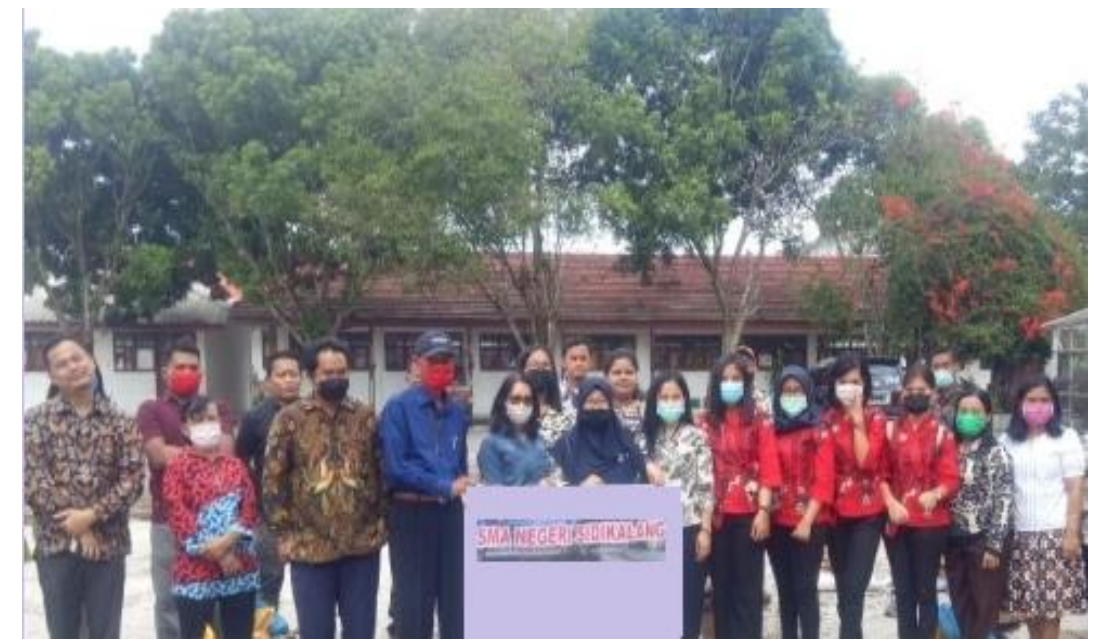

Gambar 1. Foto bersama para tim pengabdi dengan mahasiswa dan peserta pelatihan

Hasil pelatihan menunjukkan peningkatan kemampuan khalayak sasaran di dalam mengelola dan mengasuh aktifitas belajar secara daring. Contoh Classroom dan pengelolaannya diperlihatkan pada gambar 2 .

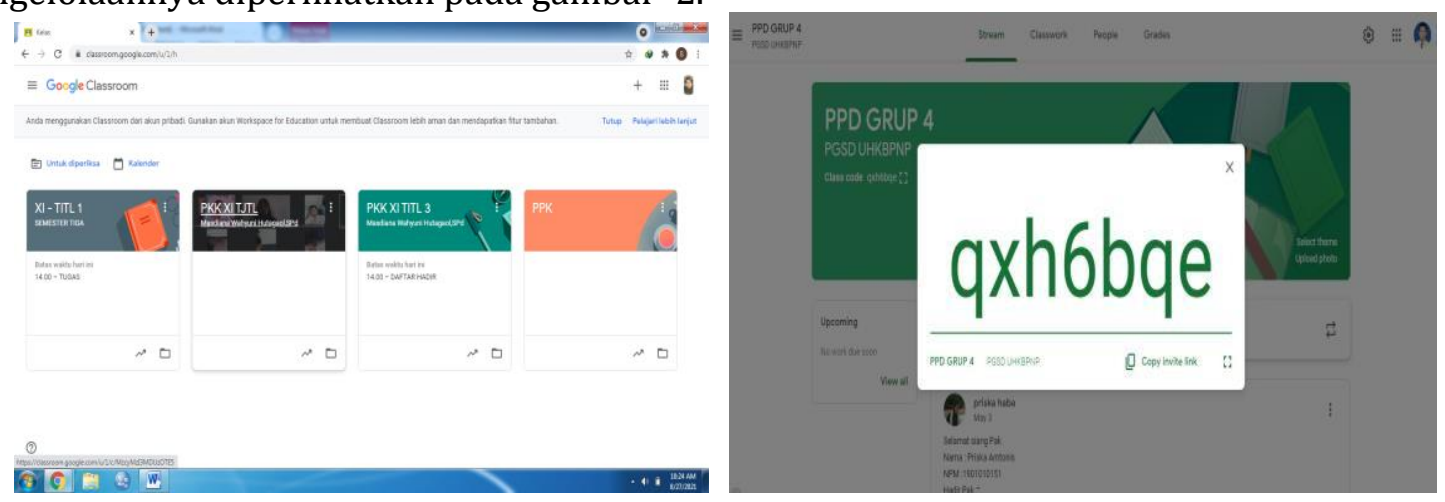

Gambar 2. Pengelolaan classroom

Setelah diberikan materi pelatihan tentang pembelajaran daring melalui penggunaan google classroom dapat dilihat bahwa persentase karakteristik guru pada pembelajaran daring yaitu 83 \% kreatif dan inovatif dan mengembangkan metode belajar dan Peningkatan mutu, relevansi penerapan model pembelajaran kontruktivistik meningkat dan $78 \%$ guru sudah dapat mengkondisikan pembelajaran yang nyata bagi siswa melalaui pembelajaran digital. Hal ini sejalan dengan hasil penelitian yang dilakukan Osco Sijabat, dkk (2021) bahwa pengaruh penggunaan google classroom sebagai media pembelajaran online dapat meningkatkan efektivitas belajar siswa. Setelah pelatihan dilakukan para guru- guru sudah dapat mengkondisikan kelas secara online hinggaproses pembelajaran dapat lebih kondusif, persentase penyesuaian karekteristik Guru yaitu 85 \% Sebagai fasilitator, motivator, dan insfirator, $15 \%$ Sebagai pendidik. Sedangkan persentase keterampilan siswa yang mampu Sharing yaitu $67 \%$, kecakapan kreatif dan inovatif siswa bertambah $18 \%$ serta persentase manfaat penggunaan video pembelajaran melalui youtube untuk siswa yaitu $86 \%$. Selain mengelola kelas, beberapa guru dan juga siswa sudah dapat membuat video pembelajaran yang di upload di chanel youtube. Screenshot contoh chanel pembelajaran dapat dilihat pada gambar 3. 
Osco Parmonangan Sijabat, Lisbet Novianti Sihombing, David Berthony Manalu, Susy Alestriani Sibagariang, Esti Marlina Sirait, Novra Melisa Hutabarat , Nurliani Siregar, Ronald Hasibuan, Injen Pardamean Butar-Butar, Herlina Hotmadinar Sianipar, Bangun Munte , Rianita Simamora

Mitra Mahajana: Jurnal Pengabdian Masyarakat 2(3), 2021, 226-231

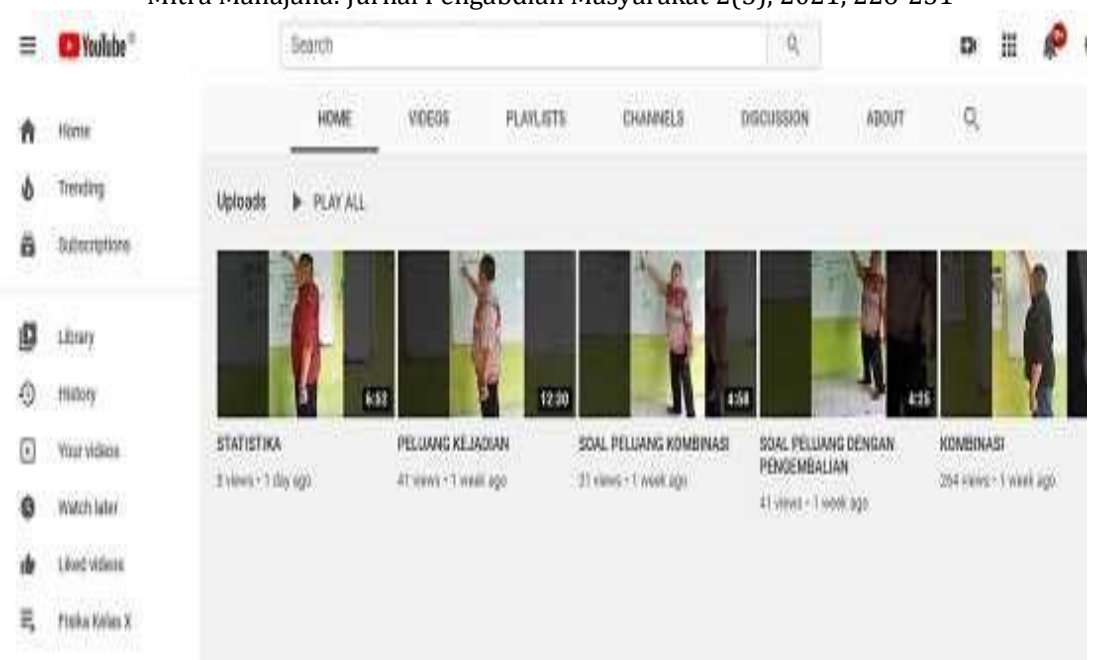

Gambar 3. Screenshot contoh channel pembelajaran

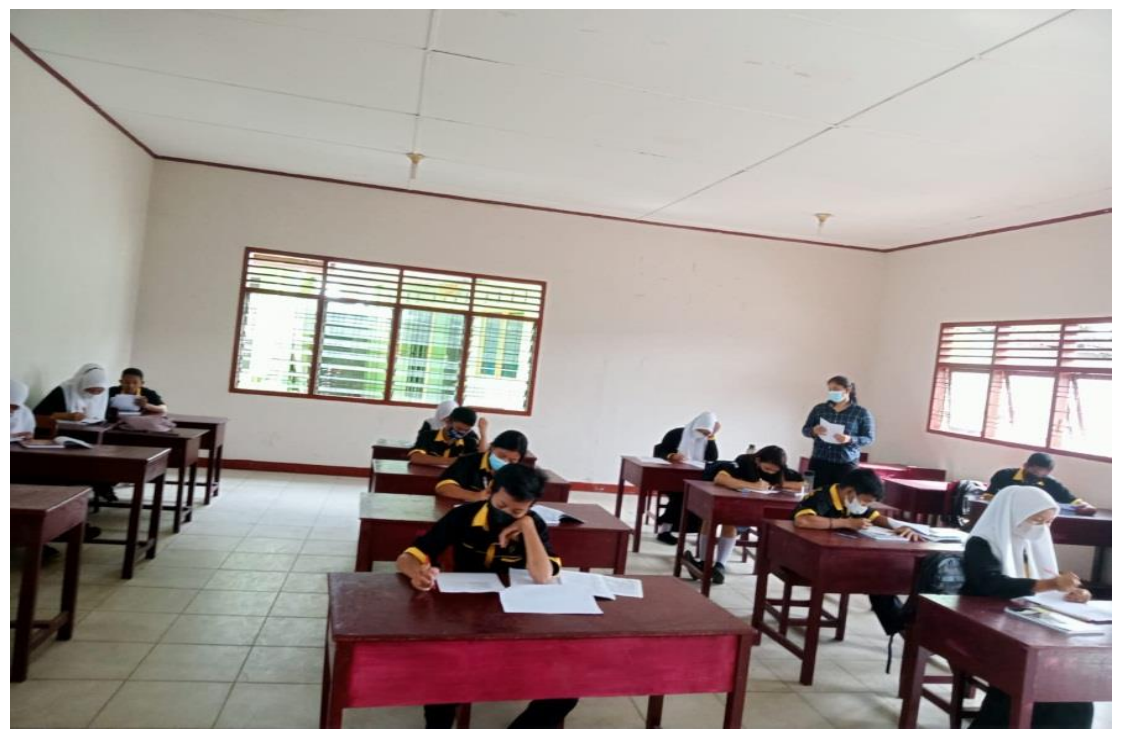

Gambar 4. Kegiatan pengabdian bersama guru dan siswa

Dari hasil kegiatan yang dilakukan selama dua hari terhadap guru-guru dan siswa di SMA Negeri 1 Sidikalang dapat diketahui melalui penyebaran angket terkait pengelolan kelas online diperoleh hasil bahwa sebelum diberikan pelatihan bapak/ibu guru lebih dari rata-rata pernah menggunakan google classroom dalam pembelajaran, namun hanya 25 peserta yang secara penuh mengimplementasikan pembelajaran daring menggunakan aplikasi google classroom. Dalam melakukan pembelajaran daring, hampir $100 \%$ peserta menggunakan aplikasi Whatsapp dalam mengimplementasikan pembelajaran dari dalam sehari-hari. Dalam proses mengajar peserta PKM mengakui bahwa mengunakan aplikasi google classroom itu mudah karena dari menjawab 100\% peserta menjawab mudah. Dalam berlangsungnya implementasi pembelajaran daring, bagi peserta PKM, tampilan Google Classroom sangat mudah dan jelas untuk dipahami dan pengunaan aplikasi google classroom mempermudah peserta memperoleh informasi mengenai tugas siswa dengan realtime. Hal ini dilihat bahwa lebih dari rata-rata yang menjawab "ya".

\section{SIMPULAN DAN TINDAK LANJUT}

Berdasarkan hasil dari pelatihan pengelolaan kelas online dapat disimpulkan bahwa penguasaan kompetensi guru dalam mengelola pembelajaran daring di lakukandengan strategi 
Osco Parmonangan Sijabat, Lisbet Novianti Sihombing, David Berthony Manalu, Susy Alestriani Sibagariang, Esti Marlina Sirait, Novra Melisa Hutabarat, Nurliani Siregar, Ronald Hasibuan, Injen Pardamean Butar-Butar, Herlina Hotmadinar Sianipar, Bangun Munte , Rianita Simamora

Mitra Mahajana: Jurnal Pengabdian Masyarakat 2(3), 2021, 226-231

penyamaan persepsi kebutuhan pembelajaran daring, pemilihan media Learning Management System ( LMS) yang sesuai dengan karakter sekolah, guru, dan peserta didik. Disamping itu, pembuatan materi pembelajaran dalam bentuk media interaktif dapat dilakukan dengan memanfaatkan media sosial yang familiar dengan peserta didik serta memberikan gairah dalam aktifitasmengajar guru dan aktifitas belajar peserta didik. Dengan demikian, kegiatan ini sangat memberikan manfaat bagi pengembangan kompetensi guru selama pandemi covid 19 dan besar harapan para guru-guru yang ada di SMA Negeri 1 Sidikalang agar kiranya tim pengabdi dari Universitas HKBP Nommensen Medan dan Pematangsiantar dapat kembali bekerja sama dengan pihak persekolahan untuk topik yang berbeda ke depan harinya.

\section{DAFTAR PUSTAKA}

Hanum, Numiek Sulistyo. (2013). Keefektifan E-learning Sebagai Media Pembelajaran (Studi Evaluasi Model Pembelajaran E-learning SMK Telkom Sandhy Putra Purwokerto). Jurnal Pendidikan Vokasi, Vol. 3, Nomor 1. 90-102

Hapsari, Swita Amalia. (2019). Pemanfaatan Google Classroom Sebagai Media Pembelajaran Online di Universitas Dian Nuswantoro. WACANA Jurnal Ilmiah Komunikasi. 18(22), 225233

Iqbal M, Rosramadhana R, Amal BK, Rumapea ME. (2018). Penggunaan Google Forms Sebagai Media Pemberian Tugas Mata Kuliah Pengantar Ilmu Sosial. Jurnal Pendidik Ilmu-Ilmu Sosial. 10(1). 120-127

Kurniawan, P.W., Zulianti, Narulita, S. (2020). Pendampingan Pembelajaran Daring melalui Aplikasi Google Meet Bagi Guru di SMA Adiguna Bandar Lampung. Adiguna:Jurnal Pengabdian dan Pemberdayaan Masyarakat, Vol. 5, No. 2, hal 133- 136

OP Sijabat,SA Sibagariang, LN Sihombing, N Siregar, HH Sianipar, Rianita Simamora, DB Manalu, Apriani Sijabat, Natalina Purba, Rudiarman Purba. (2021). Pelatihan Penggunaan Google Classroom sebagai Media Pembelajaran Daring pada Guru-Guru SD Negeri 091316 Kabupaten Simalungun. Jurnal Masyarakat Berdaya dan Inovasi (Mayadani) 2(1), 58-67.

Permata A, Bhakti YB. Keefektifan Virtual Class dengan Google Classroom dalam Pembelajaran Fisika di Masa Pandemi Covid-19. (2020). Jurnal Inovasi Pendidikan Fisika Vol. 4 No.1. 27-33.

Sawitri, D. (2020). Penggunaan Google Meet untuk Work From Home di Era Pandemi Coronavirus Disease 2019 (Covid-19). Jurnal Prioritas:Jurnal Pengabdian Masyarakat, Vol. 2, No. 1, hal 14-21 